\title{
Impact Of Financial Information Fraudulence To Financial Distress In Malaysia.
}

\author{
${ }^{1}$ Dalila Binti Abu Bakar, ${ }^{2}$ Mohamed Hisham Bin Yahya. \\ ${ }^{1}$ School of Business and EconomicsUniversiti Putra Malaysia, \\ ${ }^{2}$ Faculty Economic and Management University Putra Malaysia.
}

\section{Article History:Received:11 January 2021; Accepted: 27 February 2021; Published online: 5 April 2021}

\begin{abstract}
We investigate if Malaysian listed companies engaged in financial information fraud during financial distressed after two years of US subprime mortgage crisis.We also investigate the impact of financial information fraudulence in bankruptcy prediction and misclassification errors. This study used consumer product companies listed on the main board and the timeframe is from 2011 till 2015. The Altman Z score indicates that 37 out of 133 Malaysian consumer product companies are financially distressed. Meanwhile, the $\mathrm{M}$ score shows that 28 out of 224observations are engaged in financial information fraudulence. However, these results are relatively low because the samples are taken from the main board and fraudulence in their financial statements might be done in lower magnitude in order to avoid sanctions by the Security Exchange Commission. Logistic regression was used to measure the predicting accuracy. The result of the overall accuracy percentage slightly improved by 0.9 after eliminating fraudulent companies. The confusion matrix result i.e. before and after the removal of financial information fraudulent companies, the misclassification errors especially type one has improved. This finding satisfied objective three, whereby one of the reasons for the deterioration in financial distress prediction is due to the upward bias of financial information fraudulence.Governments, monitoring bodies, and all those involved in an insolvency process would benefit from this study.
\end{abstract}

Keywords: Financial information fraudulence, financial distressed, Z score, M score, Misclassification errors.

\section{Introduction}

Financial distress can be described as a condition when a company is unable to honor its debt obligation (Lee and Yeh, 2004; Beaver, 1966), is incapable of conducting economic activities (Honjo, 2000), has low cash flow and facing financial complications (Ding, Song and Zen, 2008; Sun et al., 2014), recorded three consecutive years of negative net income (Youn and $\mathrm{Gu}, 2010$ ), has low equity per share (Sun and $\mathrm{Li}, 2012$ ) and has a net worth less than half of its capital stock (Lee and Yeh, 2004). In general, financial distress is a company's inability to generate sufficient income to cover its expenses.

Financial distress refers to a company's financial health. The credibility of the debtor in repaying its debt is the main concern of the bondholder. Default and credit rating are significant factors that influence the investors' decision to invest their money in a certain company. The company's solvency is thus very crucial in boosting its credit image (Thai, Goh, Teh, Wong and Ong, 2014). Financial distress has been examined from various industry perspectives including small medium enterprises, services sector, financial sector (Kim and Upneja, 2014) and small market capital (Omar, Johari and Smith, 2017).

Bankruptcy declaration is the end point of a company. It is in the interest of the stockholders to avoid this unfortunate event. Reorganization is a difficult task when the company is at the edge of bankruptcy (Altman, 1983). Cost fluctuations, unexpected pricing and negative shock to revenues are among the phenomena that lead to financial distress. The tightening of credit supply and increased interest rates exacerbate financial distress and hasten bankruptcy (Battiston, Delli Gatti, Gallegati, Greenwald, and Stiglitz, 2007). Thus, this situation lures them into behaving unethically such as engaging in financial information fraudulence (Flanagan, Muse, and O'Shaughnessy, 2008).

Beasley, Carcello, and Hermanson (2001) andHasan, Omar, Barnes and Handley Schachler (2017)claimed that overstating revenues or assets helps in plummeting the company's stock price. Companies experiencing net losses or those that never reached breakeven positions have the tendency to fabricate their financial statements. The discovery of fraudulent companies always results in unfavorable outcomes such as losing investors' confidence, decreasing market value, increasing cost of capital, and losing company and manager reputation (Flanagan et al., 2008).Agrawal and Chatterjee (2015) result indicated that the engagement in financial information fraudulence among low distressed companies are high compared to that of high distressed company and it is statistically significant at a 1 percent level. The corporate event for financial information fraudulence announcement reduces the company's stock price by $8 \%$ on average (Ak, Dechow, Sun, and Wang, 2013).

Rosner (2003) concluded that failing companies manipulate earnings in pre-bankruptcy non-going-concern years. He also stated that during non-going concern year, non-stressed bankrupt companies resemble SEC fraud companies. The result showed that during going concern years, earning manipulation is lower with decreased income.Franceschetti and Koschtial (2013) argue on the Deloitte Forensic Centre Report that companies filing 
for bankruptcy protection are three times more likely to engage in financial statement fraud than non-bankrupt companies and face enforcement actions by the Securities and Exchange Commission relating to fraud behavior. Prior studies have proven that financial information fraudulence in distressed companies is still an on-going phenomenon and enhancements have been made to conceal it. Even companies with low distress levels are involved in financial information fraudulence for their personal benefit. This shows that financial manipulation techniques have evolved. Even though the issue has been discussed for decades, there is no indication that it will end anytime soon. Sophisticated accounting techniques make it even harder to be detected. Therefore, it is vital to identify fraudulent activities in the main market since most early studies had used distressed and fraudulent companies identified by the Security Exchange Commission. Previous studies had rarely highlighted the significance of financial information reliability in determining bankruptcy prediction. Although distressed companies attempted financial information fraudulence, when compared to healthy companies, their weaker position is evident. Perhaps healthy companies conceal their financial information fraudulence more successfully than distressed companies (Beaver, 1966)

This paper uses the $\mathrm{Z}$ score and the $\mathrm{M}$ score to classify financial information fraudulence among financial distressed companies in a matched sample of financially distressed and healthy companies listed on Bursa Malaysia. Second, to investigate the impact of financial information fraudulence to bankruptcy prediction accuracy; and finally to provide empirical evidence that financial information fraudulence is one of the determinant of misclassification errors.

This research makes several contributions to the extant literature. First, it investigates financial information fraudulence among distressed companies that still listed in the main board which is different from previous studiesthat used PN17 to extract distressed companies. Second, the sample focuses exclusively on consumer product companies. It empirically shown that during financial crises insolvency problems are more critical among this sectors (Hasan et al., 2017) Third, it highlight the impact of financial information fraudulence on bankruptcy prediction accuracy and misclassification errors

Our result show, some distressed companies do engaged in financial information fraudulence and the bankruptcy prediction accuracy slightly improved after financial information fraudulence removal. The misclassification errors, especially type one has improved after eliminating financial information fraudulence companies from the sample. This proved that financial information fraudulence is one of the factors eradicate bankruptcy prediction accuracy and increase misclassification errors.

The paper is structured as follows: Section 2 review previous literatures related to the field and the development of hypotheses; Section 3 discuss the methods and measurement variables used in this paper; Section 4 discuss and presenting the empirical results; and Section 5 summaries the findings and discusses their key implications and limitations.

\section{Literature Review and Hypotheses Development.}

\subsection{Financial Information Fraudulence among Financial Distressed Companies.}

Financial distress is a situation in which a firm cannot fulfil its financial obligations to its creditors, suppliers, and/or vendors (Franceschetti and Koschtial, 2013; Kim and Upneja, 2014). Financial embarrassment is when the management is aware of a company's distressed condition. Economic expansion is good but the disability of uncontrolled leverage leads to financial distress.

Minanoa and Campa (2014) found that financially distressed companies are likely to manipulate their financial information. The activities consist of the fabrication of assets, income, liabilities and losses where they no longer represent the true picture of the company. However, human beings and mistakes are inseparable whether intentionally or unintentionally. Spathis (2002) shed some light on the difference between mistakes and financial information fraudulence. He stated that financial information fraudulence is an intentional act, a scheme planned by the management to deceive stakeholders by producing fictitious documents to support the activities. Meanwhile, mistakes are unintentional errors during the financial reporting process such as misstatements or omissions of disclosure. Sometimes, errors can simply be errors; however, an increase in errors would be doubtful and could be linked to financial information fraudulence (Flanagan et al., 2008). There are several explanations as to why companies engage in financial information fraudulence including to raise capital through public offerings, to get tax exemptions, and to cover default payments and stock overvaluation (Lau and Ooi, 2016; C. Spathis, Doumpos and Zopounidis, 2002; Spathis, 2002).

Misleading financial statements pose negative and significant consequences on the information user (Crawford and Weirich, 2011; Kirkos, Spathis, and Manolopoulos, 2007). Financial information fraudulence is defined as 
the deliberate misrepresentation of the firm's financial condition accomplished through the intentional misstatement or amounts omission or disclosures in the financial statements to deceive financial statement users. Therefore, the GAAP that is used in preparing financial statement is violated (Feng and Li, 2012). Engaging in fraudulent financial information helps companies to increase their stock price (Rosner, 2003). Accounting fraud could entail fraudulent reporting and/or assets misappropriation (Kotsiantis et al., 2010; Song, Lee and Cho, 2013). Impressive sales growth and high stock returns do not always indicate a good sign (Mohan and Thakor, 2014). If the accrual is high, it could be due to financial information fraudulence since accrual is commonly used for this illegal activity (Trejo-Pech, Weldon, \& Gunderson, 2016).

Under the Association of Certified Fraud Examiners (ACFE) 2020 report, occupational fraud encompasses corruption, assets misappropriation and financial information fraudulence. There are 103 cases of fraud in Southern Asia and the median loss is up to USD117 thousand. The percentage of financial information fraudulence is 2 percent from the total occupational fraud. Even though 2 percent might seem small, when converted to actual number it is quite significant. For detail, 26 percent of the total victimized organizations are from public companies listed on the stock exchange and the estimated median loss is USD 150 thousand. In Malaysia, local companies that have engaged in financial information fraudulence are Transmile Group Berhad, Megan Media Holdings Berhad and Tat Sang Berhad.

Managers cover up the truth because its helps in avoiding useless and expensive conflicts since telling the truth might not be the most suitable strategy. Moreover, revealing unfavorable conditions leave a bad image to clients and creditors. This might lead the creditors to ask for a higher default premium (Besancenot and Vranceanu, 2009). During times of crisis, managers might prefer to communicate falsehoods to get favorable contracting terms and push down the indirect costs (Dichev and Skinner, 2002; Jaggi and Lee, 2002; Besancenot and Vranceanu, 2009).

Generally, economic crisis provides prolific grounds for companies to engage in financial information fraudulence as demonstrated by companies such as the Lehman Brothers (Grove and Basilico, 2011), Enron (Nigrini, 2005), Worldcom, Xerox, Sunbeam, Waste Management, Adelphia, Tyco, HealthSouth, Global Crossing, and others (Coates, 2007). Most major bankruptcy cases around the globe involved financial information fraud (Abbasi, Albrecht, Vance, and Hansen, 2012; Albrecht, Albrecht, and Albrecht, 2008). In early 2000, the United States criminal investigations pointed out that during the information technology bubble years, several top executives had manipulated earnings to push their companies' share value up and then cashed the overvalued stock before the company collapsed (Demski, 2003; Hall, 2003). To account for such fraudulence, the management shifted the companies' regulatory strategy in favor of tougher sanctions to decrease direct bankruptcy cost (Besancenot and Vranceanu, 2009).

\subsection{Hypothesis Development}

The agency theory discusses the relationship between the manager (which is known as agent) and the shareholders (which is the capital provider to the company managed by the agents) (Supriyanto and Darmawan, 2018). This relationship is shaped by individualistic and opportunistic interests by both parties. Incentive and compensations are created by principal as a monitoring tool to minimize the self-serving manager's actions (Abdul Hamid, Shafie, Othman, Wan Hussin, \& Fadzil, 2013). Altman (1983) does not agree that senior management needs to bear company problems and be replaced solely whenever the situation of the company is not good. The owner of the company needs to be responsible too as the objectives were set to satisfy shareholder interest. The objectives might be too ambitious that make company regulatory more toward risk seeking and possibility to fall in financial distress is high. Regulatory risk seeking company often fulfills the objective through illegal proclivities due to the low level of managerial risk taking (Khanin and Mahto, 2012). Corporate governance is one of the mechanisms that protect the company's shareholder interest. When a company needs reorganization, changes to the old management is a must to ensure that the process of rehabilitation is going well (Altman, 1983;Hutchinson, Percy and Erkurtoglu, 2008).

The manager receives great pressure to maintain decent high earnings once financial deterioration is revealed thus prompting them to overvalue the company's earnings (Ardekani, Younesi, \& Hashemijoo, 2012; Flanagan et al., 2008; Trejo-Pech et al., 2016). Moreover, the increase in CEO turnover encourages managers to engage in financial information fraudulence in order to secure their job in the company (Land, 2010). Therefore, the setting of appropriate financial incentive is critical; if the compensation is too rigid, there will be lack of superior effort and if it is too much, the employees will engage in dysfunctional behaviour. Setting long-term objectives is beneficial instead of short-term financial measurements which put pressure on the managers and employees.

However, the manager is unlikely to do so if there is no management compensation such as bonus incentives based on company earnings performance (Wells, 2002). Beasley, Carcello and Hermanson (2001) studied financial reporting fraud and found that 80 percent of it came from the top management, implicated by the Chief Executive Officer and Chief Finance Officer. They are powerful individuals who sit in the top executive position which makes it easy for them to override the internal control. However, the situation not only entails 
personal pressure received by lower position, but also personal financial pressure (compensation) (Bakri, Mohamed and Said, 2017; Hollow, 2014). Therefore, increasing manager or executive shareholding induces the incentive to engage in financial information fraudulence (Hutchinson et al., 2008). This situation is exacerbated by the fact that only one audit committee member is required to be an expert in accounting. This makes the financial statement auditing become less effective (Abdullah, Yusof and Nor, 2010).

From this angle, there are various reasons why managers manipulate earnings. Many do it as a temporary measure hoping that their company's financial condition will improve in the future. The agency theory exclusively focuses on the interconnection between the various motivations for engaging in financial information fraudulence during financial distress events. As a result, we can state our first hypothesis as follows:

Hypothesis 1: Companies that are facing financial distress practice fraudulence in their financial statements.

Financial statements are produced annually to report the companies' performance on that particular year. The annual report provides information regarding the companies' financial activities. Financial statement fraudulence committed by company executives with the purpose of hiding the actual status of the company will render the investor to have less chance of obtaining real financial information. Financial fraud is a misrepresentation of a company's financial condition accomplished through the intentional misstatement or omission of amounts or disclosures in the financial statements to deceive financial statement users (Franceschetti and Koschtial, 2013). High insecure debt proposition increases the probability of companies that have filed for bankruptcy to be liquidated (Barniv, Agarwal, \& Leach, 2002). Beatty et al. (2013) found that during scandal period, peers'1 investments are greatly associated with positive earnings overstatement amount, higher investor sentiment, a lower cost of capital and private benefits of control. Essentially, accounting information plays an important role in both the companies' own investment and other companies' investments. Beaver et al. (2012) explored the effect of financial reporting attributes on the predictive ability of financial ratios during financial distress. They found that the predictive power of financially distressed companies was substantially low compared to their counterpart. Additional variables do not provide much information of the company's distinguishing purposes. Therefore, the authors concluded that financial information fraudulence deteriorates the predictive power of the accounting model (Beaver et al., 2012) and that the analysis result will be distorted and meaningless (Beneish, 1999). Investors experience significant financial losses when they wrongly invest in distressed and financial information fraudulent companies (Dalnial, Kamaluddin, Sanusi, \& Khairuddin, 2014). Financial information fraudulent companies that persist in inflating accruals are more likely to disappear next year and those that persist in income decreasing accruals will re-appear next year (Beneish, Lee, and Nichols, 2012). Thus, moderate manipulation of financial information helps them to stay in the market. There are several reasons why companies engage in financial information fraudulence. The first reason is explained by the prospect theory which postulates the aversion to absolute and relative losses (Beneish, 1999 and Burgstahler and Dichev, 1997). Contract-based companies prefer reporting positive earnings instated of negative earnings (Daghsni, Zouhayer, \& Mbarek, 2016). Companies that have undergone mergers and acquisitions are significantly found to be engaged in financial information fraudulence one year prior to the acquisition announcement especially for share acquirer companies (Ardekani et al., 2012). The acquirer engages in stock swaps to boost its share value and reduce cost of acquisition. However, the acquirer company demonstrates underperformance once the acquisition takes place.

Related to variables based on cash flow (Beneish, 1999 and Burgstahler and Dichev, 1997) and accrual (Beneish, 1999). Managers willingly sacrifice long run economic value to satisfy short-term earnings (TrejoPech et al., 2016). Financial information fraudulence acts as a camouflage before the companies' financial state becomes healthy again. However, fraudulent activities are hard to stop once initiated and will continue for several years (Beasley, Carcello, Hermanson, \& Neal, 2010).

There are two magnitudes of earning manipulation: the first is low magnitude entailing earnings management, whilst the second is high magnitude entailing material earnings manipulation (Rosner, 2003; Trejo-Pech et al., 2016). Regardless of the magnitude, Rosner (2003) emphasised that the financial statement must look sensible to avoid detection. Therefore, financially distressed companies manipulate financial information long before being discovered by the authorities. Therefore, this stated that agency theory which is financial information fraudulence bring distortion toward financial distressed prediction accuracy. Based on the effect of financial information distortion in hindering the prediction accuracy of financial distress as highlighted in prior studies, our second hypothesis for analysis is therefore developed as follows:

H2: Financial information fraudulence deteriorates bankruptcy prediction accuracy.

It is essential for every prediction model to be able to predict or discriminate one group from another correctly. To achieve this, it is crucial to ensure that the variables used in the model have the explanatory power to distinguish between financially distressed companies from their counterpart. Incapability of doing this will

\footnotetext{
${ }^{1}$ Investment activities done without traditional financial intermediary, only individual investment and individual borrowers.
} 
weaken the model's predictive ability. The prediction model can be used as a support tool in professional settings (such as for auditors) not only in considering the recall, but also in ensuring discriminative precision. An effective predictor and the employment of correct independent and control variables will lessen misclassification errors (Bakar, Kiong, \& Nassir, 2012). If the estimator failed to label the sample of companies' correctly, it will cause investors to either lose out on potential high return investments or face investment risks. Theoretically, the ability to detect financial information fraudulence will improve financial distress prediction by making it a control variable. Thus, it helps to reduce or eliminate any irregularities in the prediction outcome that could lead to inconclusive decisions such as when the score falls under the "gray area" Cecchini et al. (2010) believe that there will be an evolvement in fraud concealment tactics in the future. Therefore, they suggest an inductive principle that anticipates this strategic behavior which might be useful in being a step ahead from the fraudster in detecting fraudulence.

Financial information fraudulence lowers the prediction model's power over time. However, market model prediction is not affected with the exclusion of restatement. Beaver et al. (2012) concluded that financial information fraudulence erodes the accounting model's predictability and cannot be offset by market-related variables. This could be seen in the appropriate coefficients. The differences in coefficient between these companies (such as inconsistence with the expected sign) may contain errors which deteriorate the predicted value. When a company fails to recognize changes in its asset values, the predictive ability of the financial ratios is impaired. Financial information fraudulence during distress period deteriorates the explanatory variables and increase misclassification errors. The authors found that there is a significant time trend in the frequency of restatements. The restatement variables significantly explained the differences in predictive ability over time. This error occurs when the model fails to correctly classify the company. Even if the market variables exhibit lower predictive power, there will be no declining time trend unlike that of the accounting variables. Therefore, due to the lack of debate in previous literatures on the factors of misclassification errors, this research aims to study the effect of fraudulence in financial information on misclassification errors. Our third hypothesis is hence developed as follows:

H3: Financial information fraudulence increases misclassification errors.

\section{Methodology}

\subsection{Sample Selection}

The population of this study entailed the consumer products industry in Malaysia The manufacturing sector had been widely used as the study sample in previous researches (Beaver, 1966; Chen, Zhang and Zhang, 2013; Foo, 2015; Kumar, 2012) due to the simplicity in ratios calculation, understandable accounting terms and finished products compared to other industries or sectors of which accounting terms are rather complex to understand. Focusing on a specific sector is essential for comparability (Andrés, Landajo, and Lorca, 2012). Comparing companies from different sectors would be problematic due to the different ratios distribution (Beaver, 1966). To make legit comparisons, the companies need to be in the same industry and of the same asset size (Thai et al., 2014).

The collected data covered the period from 2011 to 2015. The time frame was selected to avoid the structural break due to the US sub-prime crisis that hit Malaysia in late 2007 until 2008 as Charalambakis (2015) claimed that financial crisis hinders the accuracy of financial distress prediction. This notion was also supported by Chiaramonte et al. (2015) who indicated weakened prediction accuracy during the 2007-2010 financial crisis compared to during when the economy was stable (2002 to 2006) i.e. 84.62 percent and 87.09 percent, respectively. The misclassification of type one error also increased during the financial crisis period i.e. to 15.38 percent from 12.91 percent during stable economy. Consensus was made that during financial crisis, most companies are susceptible to financial distress and prediction power seems to be affected. Furthermore, accounting information for financial distress prediction during financial crisis is devolved and becomes insignificant. It is crucial to account for this systematic risk bias to alleviate substantial misclassification error, especially type one error. Thus, this study had decided to collect data starting from 2011 so as to certify that Malaysia is free from financial crisis and to circumvent the negative effect of systematic bias.

The reason for using consumer product companies instead of manufacturing companies is because there is a significant number of consumer product companies that have fallen into the PN17 status after the US sub-prime crisis (Kamaluddin, Ishak and Mohammed, 2019). This economic condition had a profound effect on the Indonesian Stock Exchange whereby Pramudena (2017) found that the share price of consumer product companies in Indonesia had experienced continuous decline after the financial crisis. The prolonged share price

2 Referring to the Z-score model by Altman (1968), if the company's Z-score falls below 1.81, it has the probability of going bankrupt or is currently facing financial distress. If the company's Z-score is above 2.99 , it is a healthy company and free from financial distress. However, if the company's Z-score falls between 1.81 and 2.99 , the result is inconclusive and a decision cannot be made. This area is known as the gray area. 
decline indicates a disruption in the companies' financial performance which led to financial distress when no corrective actions were taken by the management. The aforementioned studies showed that consumer product companies in South East Asia are significantly affected by the financial crisis considering the decline in demand for non-essential goods.

This current study adopts the purposive sampling technique where samples are determined based on certain criteria (Supriyanto and Darmawan, 2018). The cross section model is employed whereby more than one variable is collected at the same time. This technique tends to highlight the sector used in this study within the total population of listed companies in both main markets. According to Sekaran and Bougie (2013), a total of 20 percent of the sample is considered sufficient for conducting the research. There are 113 listed consumer product companies andafter calculating the Z-score ( Equation 3-1), only 37 companies are found distressed. Therefore, the 37 distressed companies are paired with the 37 healthy companies. The sample taken in this study is more than 20 percent as shown in Table 3-1.

Table 3-1: Calculation of proportionate purposive sampling

\begin{tabular}{ccc} 
Countries & Number of companies & Proportionate sampling \\
\hline Malaysia & 113 & $((37+37) / 113) \times 100 \%=65 \%$
\end{tabular}

\subsection{Estimating of Financial Distressed}

The Z-score model was introduced by Prof. Dr Edward I. Altman in 1968. It has been used widely to discriminate distressed companies with the healthy one. Therefore this study apply this model due to its ability to identify and utilize selected variables for discrimination purposes. Below is the linear combination of the Zscore model.

$$
\text { (I) } \mathrm{Z}=1.2 X_{1}+1.4 X_{2}+3.3 X_{3}+0.6 X_{4}+0.999 X_{5}
$$

Equation 3-1

Where X1 = Working capital/Total assets.

X2 = Retained Earnings/Total assets.

X3 = Earnings before interest and taxes/Total assets.

X4 = Market value equity/Book value of total debt.

$\mathrm{X} 5=$ Sales/Total assets

$\mathrm{Z}=$ Overall Index.

A score lower than 1.81 indicates a financially distressed company and be denoted as 1 . If a score higher than 2.99 indicates a healthy company and be denoted as 0 . However, a score between 1.81 and 2.99 indicates that a conclusion cannot be drawn about whether the company is financially distressed or not. This area is called the gray area or the zone of ignorance. This step was repeated on all the companies for each year. If the company experienced distress for five years straight, the number of samples would be 5 because each distressed year was counted. Healthy and distressed companies are matched based on asset size and industry (Thai et al., 2014). A reasonable number of samples are needed to cut small sample bias. Apart from helping increase the number of samples, this method had been widely used by other researchers.

\subsection{Estimating of Financial Information Fraudulence.}

The Beneish model was coined by Professor Messod Daniel Beneish and was published in 1999 with the given title "The Detection of Earnings Manipulation". He combined several ratios into the model to identify the occurrences or tendency of financial information fraudulence. This model is also known as the M-score and acts as a barometer for the extent to which earnings have been manipulated. This model was formulated using the eight ratio variable analysis to identify financial fraud occurrence or tendency to engage in earnings manipulation (Beneish, 1999). This score will help detect companies that are involved in financial information fraudulence. Table 3-2 provides the eight ratio variables used in the Beneish model to detect earning manipulations. The eight ratio variables were then calculated using the formula below:

$\mathrm{M}=-4.84+0.92 * \mathrm{DSRI}+0.528 * \mathrm{GMI}+0.404 * \mathrm{AQI}+0.892 * \mathrm{SGI}+0.115 * \mathrm{DEPI}-0.172 * \mathrm{SGAI}+4.679 * \mathrm{TATA}$ $-0.327 *$ LVGI

Equation 3-2 
Table 3-2: Eight ratio variables of the Beniesh Model

(Source: Abdul Aris et al. (2013)))

\begin{tabular}{|c|c|}
\hline Ratio & Formula \\
\hline $\begin{array}{l}\text { Sales Growth Index } \\
\text { (SGI) }\end{array}$ & Sales t / Sales (t-1) \\
\hline $\begin{array}{l}\text { Gross Margin Index } \\
(\mathrm{GMI})\end{array}$ & $\begin{array}{l}{[(\text { sales } \mathrm{t}-1-\text { cost of goods sold } \mathrm{t}-1) / \text { sales } \mathrm{t}-1] /[(\text { sales } \mathrm{t} \text { - cost of goods }} \\
\text { sold } \mathrm{t}) / \text { sales } \mathrm{t}]\end{array}$ \\
\hline $\begin{array}{l}\text { Assets Quality Index } \\
(\mathrm{AQI})\end{array}$ & (Current assets + Property, plant and equipment) / total assets \\
\hline $\begin{array}{l}\text { Days' Sales in } \\
\text { Receivable Index } \\
\text { (DSRI) }\end{array}$ & (Receivable t / sales t) / (Receivable t-1 / sales t-1) \\
\hline $\begin{array}{l}\text { Sales, General and } \\
\text { Administrative } \\
\text { Expenses Index } \\
\text { (SGAI) }\end{array}$ & $\begin{array}{l}\text { (Sales, General and Administrative Expenses t / Sales t) / (Sales, General } \\
\text { and Administrative Expenses t-1 / Sales t-1) }\end{array}$ \\
\hline $\begin{array}{l}\text { Depreciation index } \\
\text { (DEPI) }\end{array}$ & $\begin{array}{l}\text { Depreciation } \mathrm{t} / \text { Depreciation } \mathrm{t}+\text { PPE3t) / (Depreciation } \mathrm{t}-1 / \\
\text { Depreciation } \mathrm{t}-1+\text { PPE } \mathrm{t}-1 \text { ) }\end{array}$ \\
\hline $\begin{array}{l}\text { Leverage } \\
\text { (LVGI) }\end{array}$ & $\begin{array}{l}{[(\text { Long term debt } \mathrm{t}+\text { Current Liabilities } \mathrm{t}) / \text { Total Assets } \mathrm{t}] /[(\text { Long term }} \\
\text { debt } \mathrm{t}-1+\text { Current Liabilities } \mathrm{t}-1) / \text { Total Assets } \mathrm{t}-1]\end{array}$ \\
\hline $\begin{array}{l}\text { Total Accrual To } \\
\text { Total Assets (TATA) }\end{array}$ & $\begin{array}{l}(\Delta \text { Current assets }-\Delta \text { Current liabilities }-\Delta \text { short term debt }- \\
\text { Depreciation and Amortisation }- \text { deferred tax of earning }- \text { Equity in } \\
\text { Earning) / Total assets }\end{array}$ \\
\hline
\end{tabular}

An M-score result of less than -2.22 suggests that the company is not manipulating its earnings. However, an Mscore of more than -2.22 signals that the company is likely engaged in earning manipulations. A comparison between the models developed by Benford, Law and Beneish in the study by Abdul Aris et al. (2013) showed that the variables incorporated in the Beneish model is considered related to fraud detection. Different aspects of a company's performance can be assessed simultaneously instead of in isolation. The model is presumed to be reasonable, accurate and up-to-date.

\subsection{Estimating of Bankruptcy Prediction}

Logistic regression is used for examining prediction accuracy and misclassification errors for objectives 2 and 3 respectively. It is run twice to attain improvement in prediction accuracy and misclassification errors. For the first run, the model is as follows:

$$
\begin{aligned}
L_{i}=\ln \left(\frac{P_{i+\text { fraud }}}{1-P_{i+\text { fraud }}}\right)= & \beta_{1}+\beta_{2} \text { leverage ratios }+\beta_{3} \text { profitability ratios } \\
& +\beta_{4} \text { Liquidity ratios }+u_{i}
\end{aligned}
$$

Equation 3-3

In which, the financial information fraudulent companies are included in financial distressed prediction in $P_{i+f r a u d}$. As for the second run, the financial information fraudulent companies are excluded from the financial distressed prediction. The model is as follows:

\footnotetext{
${ }^{3}$ Property, plant and equipment.
} 


$$
\begin{aligned}
L_{i}=\ln \left(\frac{P_{i-\text { fraud }}}{1-P_{i-\text { fraud }}}\right)= & \beta_{1}+\beta_{2} \text { leverage ratios }+\beta_{3} \text { profitability ratios } \\
& +\beta_{4} \text { Liquidity ratios }+u_{i}
\end{aligned}
$$

Equation 3-4

This study used 17 financial ratios at the preliminary stage. Previous researchers had used these variables and found them to be useful in providing statistical evidence of distress. The stepwise method is used in the process of reducing the variables set to an acceptable number in determining the 'best' variables within the given variables set (Bae, 2012).

Table 3-3 lists the explanatory variables employed in this current study of which selection is based on their significant predictive ability as suggested in previous studies.

Table 3-3: Table of Explanatory Variables

\begin{tabular}{lll}
\hline & Variable name & Variable definition \\
\hline Profitability & S/TC & Sales/Total Capital \\
S/TD & Sales/Total Debt \\
Return on total assets & Earnings Before Interest And Tax/Total Assets \\
$\Delta$ in sales & Change in Sales \\
ROA & Profit/ Total Assets \\
ROE & Profit/ Total Equity \\
P/S & Profit/Sales \\
P/TC & Profit/Total Capital \\
Din profit & Change in Profit \\
WC/LTD & Working Capital/Long Term Debt \\
C/CL & Cash/Current Liabilities \\
Liquidity & Current Assets/Current Liabilities \\
C/TA & Cash/Total Assets \\
Debt ratio & Total Debt/Total Assets \\
TD/TE & Total Debt/Total Equity \\
Interest coverage & Earnings Before Interest and Tax/Finance Cost \\
MKTCAP/TD & Market Capital/Total Debt \\
\hline Leverage &
\end{tabular}

A suitable or best set of independent variables might give a better degree of discriminative power between the two groups of companies. The process in finding the acceptable number of variables that are closely related to the financial distress determinants is important. Further variable selection techniques were supplied for the model development process. The pair stepwise method was adopted to determine the final set of variables to be included in the discrimination model. The method starts with the step-by-step forward selection where the procedure begins with no variables in the model. Each variable's weight was evaluated at each step to determine which variable contributes most to the model's discriminative power. Variables that failed to meet the criterion (measured by Wilks' 1 statistics) were removed. This study chose the 0.80 tolerance level to stop the stepwise selection process. This is to help in choosing high-quality results with a low percentage of predictor errors, where the predictor's capability decreases as the time horizon increases.

The final profile of the variables was selected based on the following procedure: 1) observing the statistical significance of each independent variable to find the contribution; 2) checking the interrelation among the independent variables; 3 ) observing the variables' predictive accuracy, and 4) discussing the results. 


\subsection{Misclassification errors.}

Misclassification happens when a company is wrongly assigned. In objective three, type one and type two errors were calculated to observe the differences with and without the use of fraudulent companies as a control variable in predicting financial distress. Objective three applied the same variables and method as in objective two, but was split into two groups which original sample was maintained in this first round and another samples was without financial information fraudulent companies. Then, objective three produced 2 results for the misclassification errors. Below is the summarization for objective three.

Table 3-4: Classification accuracy table (Source: Altman, 1968)

\begin{tabular}{|c|c|c|}
\hline & True healthy & True financially distress \\
\hline $\begin{array}{l}\text { Prediction of healthy } \\
\text { companies }\end{array}$ & $P_{11}$ & $1-P_{11}($ Type I error $)$ \\
\hline $\begin{array}{l}\text { Prediction of financially } \\
\text { distressed companies }\end{array}$ & $1-P_{22}$ (Type II error) & $P_{22}$ \\
\hline
\end{tabular}

Based on the table above, $P_{11}$ and $P_{22}$ represent the correct classifications (hits) for healthy and financially distressed companies, respectively. Type 1 denotes misclassified financially distressed companies as healthy companies and type 2 denotes misclassified healthy companies as financially distressed companies. The results of these two misclassification errors were compared with before and after the removal of financial information fraudulent companies. This is to assess any significant differences in the misclassification results with and without financial information fraudulent companies. This study projected a differentiation in the misclassification result by taking financial information fraudulence into consideration. The expectation is that, by taking financial information into consideration, the misclassification errors could be reduced especially for type 1 error since the negative impact is more severe compared to the type 2 error.

\section{Discussion and Result}

4.1 Financial Information Fraudulence Practice among Distressed companies.

As presented in Table 4-1 the Z- score ratios were calculated for each company and it was found that there were 37 financially distressed companies. This indicates that companies listed on the main board are not always healthy. However, the companies will remain on the main board as long as they fulfill the minimum listing requirements. Financially distressed companies require some time to recover and become healthy again. The financial distress condition might be mild and the companies may still be able to meet their debt obligations.

Table 4-1: Financial Condition Analysis

\begin{tabular}{cccc}
\hline Country & Distress & Healthy & Total \\
\hline Malaysia & 37 companies & 37 companies & 74 companies \\
& (112 observations $)$ & $(112$ observations $)$ & $(224$ observations $)$
\end{tabular}

As depict in

Table 4-2, results from the Beneish model (M score) indicated that 14 (23 observations) out of 37 (112 observations) distressed companies in the sample i.e. 39 percent had been involved in financial information fraudulence at least one. This proves that some financially distressed companies engage in financial information fraudulence to improve their financial performance and to achieve other benefits (Spathis, 2002). This also proves that less distressed companies also engage in financial information fraudulence as supported by Agrawal and Chatterjee (2015). As this study used main board public listed companies, the financially distressed companies are generally healthy according to the security exchange; they were identified as financially distressed due to the Z-score.

The time frame of the study played a significant role in highlighting the consequences of economic growth relating to financial information fraudulence. After a certain economic crisis, some companies became unsustainable thus prompting their managers to embark on financial information fraudulence (Lau and Ooi, 2016). Prolonged growths have rendered corporate monitors such as regulators and auditors to believe in the companies' high performance instead of the risk indicators. Thus, this result prove that some distressed companies did practice financial information fraudulence in order to stay in the main market. Therefore, the null 
hypothesis is rejected and the result confirm that distressed companies practice financial information fraudulence

Table 4-2: Financial information Fraudulence Analysis.

\begin{tabular}{ccccc}
\hline Country & Healthy & \multicolumn{2}{c}{ Distress } & Total \\
& & Fraud & Non-fraud & \\
\hline Malaysia & 112 & 23 & 89 & 224 observations \\
& observations & observations & observations &
\end{tabular}

\subsection{The effect of financial information fraudulence on bankruptcy prediction accuracy.}

\subsubsection{Regression Analysis before Financial Information Fraudulence Removal}

The variables selected were based on the stepwise discriminate analysis. Based on the stepwise debt ratio, return on total assets and cash over total assets were found to be statistically significant at a 1 percent level whilst interest coverage and current ratio were significant at a 5 percent level. Only five variables were selected in this study as an effort to maintain the accuracy of financial distressed prediction. Fallahpour, Lakvan and Zadeh (2017) investigated the number of features that should be included in the prediction model to achieve the highest accuracy. They tested 5, 10, 15 and 20 features and found that 5 features lead to the highest accuracy. This finding was in line with that of Gogas, Papadimitriou and Agrapetidou (2018) who found that cutting the set size leads to maximum improvement over the replaced based variables. The authors indicated 6 variables for financial distress prediction.

As displayed in Table 4-3, the mean for all the variables of the healthy companies are greater than that of the financially distressed companies except for debt ratio. This is in line with Wang and Campbell (2010) who observed that the ratios of healthy companies are greater than that of financially distressed companies except for gearing ratios. The gearing ratio for financially distressed companies is higher as they need external financing to finance their business due to lack of internal financing such as retained earnings because of deficit income generation as supported by Spathis (2002). The debt ratio of healthy companies is twice lower than that of their counterpart. Interest coverage for healthy companies is 103 times greater than that of financially distressed companies. Assets turnover, current ratio and cash over assets are 6,2 and almost twice times greater than that of financially distressed companies. In conclusion, the financial performance of healthy companies is significantly distinct than that of its counterpart. The current ratio and cash to total assets ratios of financial distressed companies are approximately half of the healthy companies. This shows that financially distressed companies have a liquidity problem rendering a high possibility for them not being able to fulfill their obligation (Spathis, 2002).

Table 4-3: Descriptive Analysis for Malaysia before removing Fraud companies.

\begin{tabular}{lcccc}
\hline & \multicolumn{2}{c}{ Healthy } & \multicolumn{2}{c}{ Financially distress } \\
\hline Debt ratio & Mean & Sta. Deviation & Mean & Sta. Deviation \\
Interest coverage & 0.2696 & 0.1546 & 0.4948 & 0.1814 \\
Return on total assets & 628.5856 & 2826.6660 & -6.1412 & 25.0946 \\
Current ratio & 0.1659 & 0.1117 & -0.0320 & 0.1500 \\
Cash/TA & 4.2303 & 5.1639 & 2.2695 & 6.8553 \\
\hline
\end{tabular}

Multicollinearity was conducted to ensure that none of the independent variables are correlated to each other. Four ratios were identified in this process namely financial leverage ratios, profitability ratios, cash flow ratios and growth. Financial leverage ratios consist of another four ratios namely debt ratio, interest coverage, market value of equity to book value of total debt (BV/TD) and current liabilities to total assets. The three ratios of sales to total assets (SALES/TA), retained earnings to total asset (RE/TA) and return on total assets were used for profitability ratios. Cash flow ratios were represented by working capital to total asset (WC/TA), cash to total assets (CASH/TA) and current ratio (CA/CL). Last but not least, the measurement of company growth employed changes in sales ( $\triangle$ SALES) as the indicator. The process was run twice, one for the Malaysian sample and the other for the Singapore sample.

Table 4-4: Correlation table for Malaysia before removing Fraud companies.

\begin{tabular}{llll}
\hline Debt ratio & $\begin{array}{l}\text { Interest } \\
\text { coverage }\end{array}$ & $\begin{array}{l}\text { Return on total Current ratio Cash/TA } \\
\text { assets }\end{array}$
\end{tabular}

Debt ratio 1




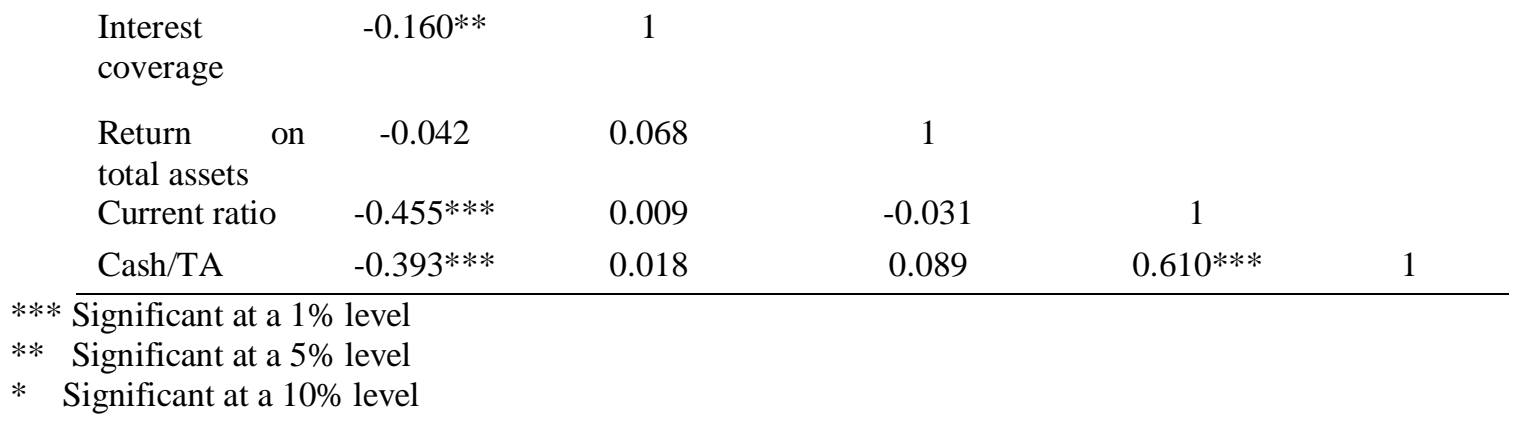

In searching for a robust result, the test was run several times and it was concluded that five independents variables produce optimal results by using the stepwise logistic regression. Debt ratio and interest coverage represent financial leverage and return on total assets for profitability ratio, whilst cash flow ratios consist of cash ratio and current ratio. Table 4-4 confirms that the pairwise correlations among the variables are uniformly low except for debt ratio and interest coverage, debt ratio and current assets, debt ratio and cash over total assets, and current ratio and cash over total assets. Debt ratio has a low correlation with interest coverage but moderate correlation with current ratio and cash over total assets. Current ratio has a moderate correlation with cash over total assets. Based on the table above, all the correlation values are not more than 1 and not less than 1. The highest correlation only goes up to 1 whereby when the independent variable is tested upon itself it will be highly correlated. To check the correlation between the current ratio and itself, the result should be 1 because of the self-to-self correlation. However, when the correlation is tested on different variables, the result should be between 0.6 and -0.6 to show that they are not correlated to each other. As depicted in Table 4-4, all the variables are not correlated with each other except for the current ratio with cash ratio which recorded a result of 0.610 i.e. exceeding 0.6. This means that these variables are correlated and thus need to be dropped. As mentioned earlier, these ratio selections are not grounded upon any theoretical reason except for the popularity of usage and predictive ability as proven in previous literatures. The simplest way is to drop either one of the variables; however, this action could probably cause worse problems than multicollinearity issues when running the logistic regression later. The independent variables were re-examined to check the seriousness of the multicollinearity problem by running the multicollinearity test using Variance Inflation Factors (VIF).

Table 4-5: Variance Inflation Factors (VIF) for Malaysia before removing Fraud companies.

\begin{tabular}{lcc}
\hline Model & \multicolumn{2}{c}{ Collinearity statistics } \\
& Tolerance & VIF \\
\hline Constant & - & - \\
Debt ratio & 0.822 & 1.216 \\
Interest coverage & 0.968 & 1.033 \\
Return on total assets & 0.988 & 1.012 \\
Cash/TA & 0.838 & 1.193
\end{tabular}

The variance inflation factor determines how much the coefficient variance estimate had inflated due to collinearity with other variables. It portrays a variable's actual variance to the perfect variance of zero collinearity. The value of 0.1 was used as the tolerance cut off; hence, the variance inflation factor should not be more than 10. If it exceeds the value of 10 , serious problems of collinearity will occur rendering it to be dropped from the estimation. Current ratio is set as the dependent variable against other independent variables. The VIF result shows that all the variables figured below 10 which indicate that multicollinearity is not a threat in this study.

Table 4-6: Logistic result for Malaysia before removing Fraud companies.

Coefficient Standard Error

\begin{tabular}{lcc}
\hline Debt ratio & $27.634 * * *$ & 8.826 \\
Interest coverage & $-0.382^{*}$ & 0.225 \\
Return on total assets & $-59.467 * * *$ & 22.448
\end{tabular}


Current ratio

Cash/TA

Constant
0.236

$-4.273 *$
0.197

2.427

*** Significant at a $1 \%$ level

** Significant at a $5 \%$ level

* Significant at a $10 \%$ level

Table 4-6 presents the results of the determinants of financial distress for Malaysia by using the logistic model. It suggests current ratio, cash to total assets, debt ratio, interest coverage, and return on total assets as the determinants of financially distressed companies in Malaysia. All the selected independent variables are statistically significant except for current ratio and cash over total assets. Debt ratio and return on total assets are found to be statistically significant at one percent and interest coverage statistically significant at ten percent.

Theoretically, excessive amounts of current assets help to provide liquidity and assist as a cushion in meeting short term obligations or contingencies. It is essential for companies to have more current assets than current liabilities in order to remain healthy. Deterioration in this ratio will increase the tendency of financial distress. However, the result is contra wise for the Malaysian companies whereby an increase in the current ratio lowers the capability of the companies in serving their short term debts and increasing their tendency of becoming financially distressed. Perhaps the financial items contained in current assets had been manipulated as found by Rosner (2003) that account receivable, inventory and account payable are frequently used by manipulators for the purpose of earning management. This result is in line with that of Beasley et al. (2010) who found that inventory and account receivable make up the first and second highest fraud cases and account misstatements. This could explain the positive coefficient for current assets even though it is not significant.

Cash over total assets has a negative correlation with financially distressed companies which is consistent with the expected sign even though it is not statistically significant. This proves that companies with excessive cash are more likely to generate more profit by injecting surplus funds into positive projects or investing in fixed assets to increase production. Underutilized funds made it difficult for companies to repay their debts during when the economy was still recovering from the US subprime mortgage crisis.

The debt ratio is consistent with the expected sign, where normally, companies are susceptible to financial distress with excessive amounts of debt. A high debt ratio indicates that a company might face difficulties in servicing its debt. This is especially true when the economy is in the recovery stage where banks may charge high interests; it could be worse for companies that borrowed during recession. Some companies struggle in meeting the cost of debt and thus have to maintain discipline in repaying their debts. High debts will restrain a company from undertaking positive net present value projects. This result is in line with the interest coverage ratio where the company has surplus earnings after satisfying cost and expenses to pay the interest. High earnings before interest and tax will increase the chances of a company to utilize the fund and service the cost of debt. The surplus fund could be used to undertake new projects that can generate more profit. High interest coverage ratio is vital to ensure a company's survivability in the business and provides a cushion during crisis.

Return on total assets measures the effectiveness of a company in using its assets, whereby a higher assets turnover ratio is indicative of greater efficiency in managing total asset investments. The result agrees with the expected theory, which indicates that a higher return on total assets will lower the tendency of the company to fall into financial distress. This result is in line with that of Alifiah et al. (2013) which predicted financially distressed companies in the consumer product sector in Malaysia. Wang and Campbell (2010) also found that this ratio is statistically significant at a 5 percent level in predicting financial distress. Table 4-6 shows that the coefficient of the return on total assets is the highest among other variables and is statistically significant at a 1 percent level. This is in line with the findings of Inam, Inam, Mian, Sheikh and Awan (2019) which observed that return on total assets is the best predictor in the context of Pakistan. This ratio reports the return that a company generates for every cent of investment in total assets. Fully utilized total assets are vital to ensure maximized company returns. Therefore, it can be concluded that all the independent variables used in the model follow the expected sign except for current ratio which is suspected to be vulnerable towards financial information fraudulence.

Based on the Hosmer and Lemeshow test, the chi-square is 0.269 and not statistically significant. This test concludes that under goodness-of-fit, this model is a good fit for predicting financial distress in the Malaysian context. Apart from that, the R square for this model is between 73 percent and 97 percent which means that the variance in the dependent variable is explained by our model and this is considered high and good.

Table 4-7: Confusion Matrix for Malaysia before removing Fraud companies

True healthy True distress Class Precision


Prediction healthy

Prediction distress

Overall percentage
111

1 (Type 2)
$99.1 \%$

$99.1 \%$

$99.1 \%$

This study employed matching samples where 37 companies were classified as financially distressed under the Altman Z-score and paired with the 37 healthy companies that share the same characteristics in terms of assets size. Thus, there were 224 observations for both financially distressed and healthy companies with 112 companies each. According to Table 4-7, none of the companies were dropped due to missing values. The accuracy of the logistic model in identifying healthy companies is 99.1 percent of which only 0.9 percent was for type two error. This is the same with the financially distressed companies where 99.1 percent of the sample was correctly classified and only 0.9 percent was for type one error. Overall, the prediction model accuracy is 99.1 percent which is considered high and good. Only one company was misclassified for each. This is good as the opportunity cost is very low and the tendency for the investors to miss a chance to invest in a positive net present value project is also low.

\subsubsection{Regression Analysis after Financial Information Fraudulence Removal}

Table 4-8: correlation matrix for Malaysia after Fraud.

\begin{tabular}{lccccc}
\hline & Debt ratio & $\begin{array}{l}\text { Interest } \\
\text { coverage }\end{array}$ & $\begin{array}{l}\text { Return on } \\
\text { total assets }\end{array}$ & Current ratio & Cash/TA \\
\hline $\begin{array}{l}\text { Debt ratio } \\
\begin{array}{l}\text { Interest } \\
\text { coverage }\end{array}\end{array}$ & $-0.178^{* *}$ & 1 & & \\
$\begin{array}{l}\text { Return on } \\
\text { total assets } \\
\text { Current ratio }\end{array}$ & -0.055 & 0.074 & 1 & & \\
$\begin{array}{l}\text { Cash/TA } \\
\text { Cash }\end{array}$ & $-0.454 * * *$ & 0.005 & -0.055 & 1 & \\
\hline
\end{tabular}

*** Significant at a $1 \%$ level

** Significant at a $5 \%$ level

* Significant at a $10 \%$ level

The second test was conducted to observe any significant changes if companies engaged in financial information fraudulence were dropped from the sample. As exhibited in Table 4-8, there is a slight difference from the previous result in terms of level of correlation, but the statistical significance remains the same. The second test showed the existence of a correlation between the current ratio and cash over total assets. Thus, the variance inflation factor test was carried out and according to the result in Table 4-9, the VIF is lower than 10. This means that multicollinearity is not a serious issue in this study.

Table 4-9: Variance Inflation Factors (VIF).

\begin{tabular}{lcc}
\hline Model & \multicolumn{2}{c}{ Collinearity statistics } \\
& Tolerance & VIF \\
\hline Constant & - & - \\
Debt ratio & 0.818 & 1.222 \\
Interest coverage & 0.959 & 1.042 \\
Return on total assets & 0.988 & 1.012 \\
Cash/TA & 0.841 & 1.189
\end{tabular}

Table 4-10: Logistic result for Malaysia after Fraud. 


\begin{tabular}{lcc}
\hline & Coefficient after fraud & Coefficient before fraud \\
\hline Debt ratio & -276.919 & $27.634^{* * *}$ \\
Interest coverage & 6.245 & $-0.382^{*}$ \\
Return on total assets & 624.066 & $-59.467 * * *$ \\
Current ratio & -3.550 & 0.236 \\
Cash/TA & 180.483 & -4.224 \\
Constant & 40.917 & $-4.273^{*}$ \\
\hline
\end{tabular}

*** Significant at a $1 \%$ level

** Significant at a 5\% level

* Significant at a $10 \%$ level

As portrayed in table 4-10, after removing financial information fraudulence from the sample, the variables' coefficient becomes statistically insignificant. The relationship between the variables becomes the opposite of the earlier result. There are significant differences in the coefficient after financial information fraudulence is dropped and the impact varies between the samples. As observed in Table 4-10, debt and current ratios have a negative relationship with financially distressed companies whilst interest coverage, return on total assets and cash over total assets are positively correlated with financially distressed companies. After removing financial information fraudulence, only current ratio retains the expected finding. Normally, healthy companies have strong revenues with returns soaring upward over time and vice versa for financially distressed companies. The result shows that after removing financial information fraudulent companies, the interest coverage is positively associated with financial distress whereby the higher the interest coverage of the company, the higher the risk for the company to experience financial distress.

This means that financial information fraudulence distorts the independent variables' predictive power as claimed by previous researchers (Beasley et al., 2010; Hasan et al., 2017; Perols and Lougee, 2011; Rosner, 2003) who found that some items such as revenue, cost, accruals, depreciation, assets and cash flow are manipulated to produce decent profit. Compared to healthy companies, managers of financially distressed firms are more likely to inflate core or operating profits to reach or exceed earnings benchmarks (Nagar and Sen, 2017). They do so by misclassifying central or operating costs as special products that minimize revenue. On top of that, Franceschetti and Koschtial (2013) stated that healthy companies that are leaning towards insolvency tend to engage in financial information fraudulence. This is also supported by Rosner (2003) who stated that healthy companies produce more red flags then distressed companies.

Roughly, after comparing the results of the robustness of the logistic regression model, it can be concluded that the significance of the variables deteriorates and only current ratio is corrected after removing financial information fraudulent companies. One explanation is that perhaps since the study does not cover fraudulent activities conducted in healthy companies, there is a possibility that healthy companies might also engage in financial information fraudulence but in different magnitudes (mild or low).

After removing financial information fraudulent companies from the analysis, the $\mathrm{R}$ square for this model is between 75 percent and 100 percent to describe the variance in the dependent variable which is quite high and good for the distress prediction. The independent variable used for distress prediction seems to improve compared to before the financial information fraudulent companies were removed.

Table 4-11: Confusion Matrix for Malaysia after Fraud.

\begin{tabular}{llll}
\hline & True healthy & True distress & Class Precision \\
\hline Prediction healthy & 89 & 0 (Type 1) & $100 \%$ \\
Prediction distress & 0 (Type 2) & 89 & $100 \%$ \\
Overall percentage & & & $100 \%$
\end{tabular}

Out of 224 observations, 23 observations were found to be financial information fraudulent companies and thus removed from the sample leaving a total of 201 observations. The 23 observations is equivalent to 14 companies 
that engage in financial information fraudulence at least once during the set time frame. It is to seek any improvement in the model prediction accuracy. A total of 23 observations were reported as missing cases thus leaving a remaining 178 observations as sample. The removal of the 23 missing cases is to curb outliers and to ensure the robustness of the result. As depicted in table 4-11, none of the observations were misclassified after removing the financial information fraudulent companies. Thus, no classification errors occurred in this sample. The result became more robust after taking care of the financial information fraudulent companies compared to the previous result of 0.9 percent for both types one and two errors. Thus, the overall prediction for the logistic regression after eliminating financial information fraudulent companies became 100 percent. This means that removing financial information fraudulent companies does improve prediction accuracy even though if it is only 0.9 percent from the previous result. This in line with previous literatures where the model should be improved after taking care of those companies (Liou and Yang, 2008).

\subsection{The determinants for Misclassification Errors}

This sub-topic aims to confirm whether the misclassification error is caused by financial information fraudulence for both countries especially on the main board market. Table 4-12: Misclassification Errors for Malaysia. 3 show that the misclassification error for types one and two was reduced from 0.9 to 0 percent. The accuracy of predicting financial distress increased by 0.9 percent i.e. from 99.1 percent to 100 percent after dropping financial information fraudulent companies from the sample.

Table 4-12: Misclassification Errors for Malaysia.

\begin{tabular}{lllllll}
\hline Country & $\begin{array}{l}\text { Type 1 } \\
\text { before }\end{array}$ & after & $\begin{array}{l}\text { Type 2 } \\
\text { before }\end{array}$ & after & $\begin{array}{l}\text { Total } \\
\text { before }\end{array}$ & after \\
\hline Malaysia & $0.9 \%$ & $0 \%$ & $0.9 \%$ & $0 \%$ & $0.9 \%$ & $0 \%$ \\
\hline
\end{tabular}

The predictive ability had improved overtime after treating the sample. This proves that misclassification errors do happen on the main board. The result indicates that accuracy prediction becomes more robust when financial information fraudulent companies are removed. This is in line with the findings by Liou and Yang (2008) which suggest that removing financial information fraudulent companies in advance from the financial distressed prediction can effectively enhance prediction accuracy. In their study, the prediction accuracy increased by 3 percent i.e. from 88 percent to 91 percent after removing financial information fraudulent companies. Thus, it can be concluded that financial information fraudulence is one of the determinants in misclassification error especially for type one.

\section{Conclusion}

This study is an empirical investigation on the effect of financial information fraudulence on financial distress prediction in Malaysia. The aim of this study is to contribute to the existing knowledge on financial information fraudulence and financial distress prediction by focusing on misclassification error especially type one error. Firstly, the study explored the existence of financial information fraudulence among financially distressed companies in Malaysia. Secondly, it identified the determinants of financial distress prediction and recorded the misclassification errors before data treatment was carried out. Lastly, it examined the improvement of misclassification errors after financial information fraudulent companies were treated or removed from the sample.

Pertaining to the first objective, the study is motivated by the lack of literatures that highlight the existence of established models that can be directly utilized in the main market instead of waiting for authoritative bodies to come out with investigation reports or rumors on company financial information fraudulence activities. This study focuses on manufacturing companies listed on the Bursa Malaysia. The time frame of the study is three years after world was hit by the US sub-prime mortgage crisis. This study utilized the Beneish model known as the M-score to identify fraudulent activities in financial statements. The Altman Z-score was used to identify healthy and financially distressed companies on the main market. The selected models for discriminating purposes had been widely used in past studies and had demonstrated a remarkable performance.

The result revealed that some companies still have financially distressed symptoms according to the Z-score value even after three years of the economic crisis. The result shows that developing countries take a long time to recover after the crisis. The Beneish M-score was used to identify financial information fraudulent companies. The test was on distressed companies only and it was unfolded that there were initiatives taken by the top management to conceal the companies' poor financial performance.

Comparative action has been taken to investigate the progress after fraud companies have been removed in evaluating the effect of financial information fraudulence on bankruptcy accuracy results. After financial information fraudulence was excluded from the study, the logistic result indicated that bankruptcy prediction accuracy improved. This suggests that financial information tainted the accuracy of the predictions.If we compare the type one, type two and overall percentage of misclassification errors with before and after financial 
information fraudulence, it has been shrinking from $0.9 \%$ to $0 \%$. Therefore, we concluded that financial information fraudulence is one of the determinants of misclassification errors.

This study is important for creating awareness among investors that financial information fraudulence is happening in the capital market because the management needs to meet or beat the analysis forecast (Perols and Lougee, 2011). Therefore, the tone set by the management is relevant and rational for them despite being unethical. This unlawful activity will persist as long as it is not detected by the Security Exchange Commission (Lau and Ooi, 2016). However, once the perpetrator is caught and revealed to the public, the downturn impact is severe. Not only will the fraudulent company receive a penalty, those in abetment will also have to pay a huge amount due to the damage done towards the investors and for breach of trust. Creditors and financial institutions may utilize the findings of this study to measure the financial status of companies before granting loans and credit facilities. This is to avoid giving credit facilities to distressed companies that are suspected to be engaged in financial information fraudulence. The findings of this study are also beneficial for auditors in evaluating the going concern status of current and future companies that they would like to investigate. This study also highlights the importance of setting a standard in selecting auditors and clearing benchmarks for nominating an audit committee. Therefore, the audit work can be done in a diligent and transparent manner. This explains the government's initiative in having companies to rotate their auditor every five years (Anastasopoulos and Anastasopoulos, 2012).

Several areas had been identified for exploration in future research. Firstly, there is room to explore in other sectors in Malaysia or even other countries. Findings on other sectors and countries will contribute to the existing knowledge on financial information fraudulence and financial distress. Therefore, in-depth investigations can be conducted by result comparison. Secondly, this research had only focused on main market and public listed companies. Thus, future studies can focus on other markets such as the secondary market, the ACE market or private companies. These markets are rarely explored due to issues regarding data availability; however, explorations on these markets will give a variation to the intended discipline. Thirdly, future researchers can use other methods than the Altman Z-score and the Beneish M-Score to identify financial distress and financial information fraudulence such as the Jones model and Modified Jones model. The main reason for using the Altman Z-score and Beneish M-Score is their simplicity. Perhaps, using sophisticated discriminate models could produce more reliable and robust results.

\section{Reference}

1. Abbasi, A., Albrecht, C., Vance, A., \& Hansen, J. (2012). Meta Fraud: A Meta-Learning framework for detecting financial fraud. MIS Quarterly, 36(4), 1293-1327.

2. Abdul Aris, N., Othman, R., Mohd Arif, S. M., Abdul Malek, M. A., \& Omar, N. (2013). Fraud Detection: Benford' s Law vs Beneish Model. In IEEE Symposium in Humanities, Science and Engineering Research (SHUSER)726-731.

3. Abdul Hamid, F. Z., Shafie, R., Othman, Z., Wan Hussin, W. N., \& Fadzil, F. H. (2013). Cooking the Books: The Case of Malaysian Listed Companies. International Journal of Business and Social Science, 4(13), 179-186.

4. Abdullah, S. N., Yusof, N. Z. M., \& Nor, M. N. M. (2010). Financial restatements and corporate governance among Malaysian listed companies. Managerial Auditing Journal, 25(6), 526-552.

5. ACFE. (2020). Report to the Nations on Occupational Fraud and Abuse

6. Agrawal, K., \& Chatterjee, C. (2015). Earnings Management and Financial Distress : Evidence from India. Global Business Review, 16(5), 140-154.

7. Ak, B. K., Dechow, P. M., Sun, Y., \& Wang, a. Y. (2013). The use of financial ratio models to help investors predict and interpret significant corporate events. Australian Journal of Management, 38(3), 553-598.

8. Albrecht, W. S., Albrecht, C., \& Albrecht, C. C. (2008). Current trends in fraud and its detection. Information Security Journal: A Global Perspective, 17(1), 2-12.

9. Alifiah, M., Salamudin, N., \& Ahmad, I. (2013). Prediction of Financial Distress Companies in the Consumer Products Sector in Malaysia. Jurnal Teknologi, 64, 85-91.

10. Altman, E. I. (1983). Exploring the Road to Bankruptcy. Journal of Business Strategy, 4(2), 36-41.

11. Anastasopoulos, N. P., \& Anastasopoulos, M. P. (2012). The Evolutionary Dynamics of Audit. European Journal of Operational Research, 216(2), 469-476.

12. Andrés, J. De, Landajo, M., \& Lorca, P. (2012). Bankruptcy prediction models based on multinorm analysis: An alternative to accounting ratios. Knowledge-Based Systems, 30, 67-77.

13. Ardekani, A. M., Younesi, N., \& Hashemijoo, M. (2012). Acquisition, Earnings Management and Firm's Performance: Evidence from Malaysia. Journal of Business Studies Quarterly, 4(1), 91-110.

14. Bae, J. K. (2012). Predicting financial distress of the South Korean manufacturing industries. Expert 
Systems with Applications, 39(10), 9159-9165.

15. Bakar, S., Kiong, I. T. W., \& Nassir, A. M. (2012). Examining and Validating a Bankruptcy Prediction Models in Malaysia. In Statistics in Science, Business, and Engineering (ICSSBE) 220-224.

16. Bakri, H. H. M., Mohamed, N., \& Said, J. (2017). Mitigating asset misappropriation through integrity and fraud risk elements: Evidence emerging economies. Journal of Financial Crime, 24(2), 242-255.

17. Barniv, R., Agarwal, A., \& Leach, R. (2002). Predicting Bankruptcy Resolution. Journal of Business Finance and Accounting, 29(2000), 497-518.

18. Battiston, S., Delli Gatti, D., Gallegati, M., Greenwald, B., \& Stiglitz, J. E. (2007). Credit chains and bankruptcy propagation in production networks. Journal of Economic Dynamics and Control, 31(6), 2061-2084.

19. Beasley, M. S., Carcello, J. V, and Hermanson, D. R. (2001). Financial Reporting Fraud: Could It Happen to You? The Journal of Corporate Accounting and Finance, 12(4), 3-9.

20. Beatty, A., Liao, S., \& Jiewei, J. (2013). The spillover effect of fraudulent financial reporting on peer. Journal of Accounting and Economics, 55(2-3), 183-205.

21. Beaver, W. H. (1966). Financial Ratios as Predictors. Journal of Accounting Research, 4, 71-111.

22. Beaver, W. H., Correia, M., \& Mcnichols, M. F. (2012). Do differences in financial reporting attributes impair the predictive ability of financial ratios for bankruptcy? Review of Accounting Studies, 17(4), 969-1010.

23. Beneish, M. D. (1999a). The Detection of Earnings Manipulation. Financial Analysts Journal, 55(5), 24-36.

24. Beneish, M. D., Lee, C. M. C., and Nichols, D. C. (2012). Fraud Detection and Expected Returns. SSRN Working Paper, 1-52.

25. Besancenot, D., \& Vranceanu, R. (2009). Strategic managerial dishonesty and financial distress. Research in Economics, 63(1), 11-21.

26. Burgstahler, D., \& Dichev, I. (1997). Earnings management to avoid earnings decreases and losses. Journal of Accounting and Economics, 24(1), 99-126.

27. Cecchini, M., Aytug, H., Koehler, G. J., \& Pathak, P. (2010). Detecting Management Fraud in Public Companies. Management Science, 56(7), 1146-1160.

28. Charalambakis, E. C. (2015). On the prediction of corporate financial distress in the light of the financial crisis: Empirical evidence from Greek listed firms. International Journal of the Economics of Business, 1516, 1-22.

29. Chen, Y., Zhang, L., \& Zhang, L. (2013). Financial Distress Prediction for Chinese Listed Manufacturing Companies. Procedia Computer Science, 17, 678-686.

30. Chiaramonte, L., Croci, E., \& Poli, F. (2015). Should we trust the Z-score? Evidence from the European Banking Industry. Global Finance Journal, 28, 111-131.

31. Coates, J. C. (2007). The Goals and Promise of the Sarbanes-Oxley Act. Journal of Economic Perspectives, 21(1), 91-116.

32. Crawford, R. L., \& Weirich, T. R. (2011). Fraud guidance for corporate counsel reviewing financial statements and reports. Journal of Financial Crime, 18(4), 347-360.

33. Daghsni, O., Zouhayer, M., \& Mbarek, K. B. H. (2016). Earnings Management and Board Characteristics: Evidence from Malaysia. Account and Financial Management Journal, 1(2), 92-110.

34. Dalnial, H., Kamaluddin, A., Sanusi, Z. M., \& Khairuddin, K. S. (2014). Accountability in Financial Reporting: Detecting Fraudulent Firms. Procedia - Social and Behavioral Sciences, 145, 61-69.

35. Demski, J. S. (2003). Corporate Con icts of Interest. Journal OfEconomic Perspectives, 17(2), 51-72.

36. Dichev, I. D., \& Skinner, D. J. (2002). Large-sample evidence on the debt covenant hypothesis. Journal of Accounting Research, 40(4), 1091-1123.

37. Ding, Y., Song, X., \& Zen, Y. (2008). Forecasting financial condition of Chinese listed companies based on support vector machine. Expert Systems with Applications, 34(4), 3081-3089.

38. Fallahpour, S., Lakvan, E. N., \& Zadeh, M. H. (2017). Using an ensemble classifier based on sequential floating forward selection for financial distress prediction problem. Journal of Retailing and Consumer Services, 34(October 2016), 159-167.

39. Feng, M., and Li, C. (2012). How do earnings manipulators guide investors? Working paper, University of Pittsburgh and University of Washington

40. Flanagan, D. J., Muse, L. A., \& O'Shaughnessy, K. C. (2008). An overview of accounting restatement activity in the United States. International Journal of Commerce and Management, 18(4), 363-381.

41. Foo, S. L. (2015). Financial Health \& Corporate Performance of Listed Manufacturing Companies in Hong Kong \& Singapore : A Comparative Study of the Two Asian Tigers, 03(02), 148-154.

42. Franceschetti, B. M., \& Koschtial, C. (2013). Do bankrupt companies manipulate earnings more than the non- bankrupt ones? Journal of Finance and Accountancy, 12, 1-22.

43. Gogas, P., Papadimitriou, T., \& Agrapetidou, A. (2018). Forecasting bank failures and stress testing: A 
machine learning approach. International Journal of Forecasting, 34(3), 440-455.

44. Grove, H., \& Basilico, E. (2011). Major financial reporting frauds of the 21st century: Corporate and risk lessons learned. Journal of Forensic and \& Investigative Accounting, 3(2), 191-226.

45. Hall, B. J. (2003). Six challenges in designing equity-based pay. Journal of Applied Corporate Finance, 15(3), 21-33.

46. Hasan, M. S., Omar, N., Barnes, P., \& Handley Schachler, M. (2017). A cross-country study on manipulations in financial statements of listed companies Evidence from Asia. Journal of Financial Crime, 24(4), 656-677.

47. Hollow, M. (2014). Money, morals and motives: An exploratory study into why bank managers and employees commit fraud at work. Journal of Financial Crime, 21(2), 174-190.

48. Honjo, Y. (2000). Business failure of new firms: an empirical analysis using a multiplicative hazards model. International Journal of Industrial Organization, 18(4), 557-574.

49. Hutchinson, M. R., Percy, M., \& Erkurtoglu, L. (2008). An investigation of the association between corporate governance, earnings management and the effect of governance reforms. Accounting Research Journal, 21(3), 239-262.

50. Inam, F., Inam, A., Mian, M. A., Sheikh, A. A., \& Awan, H. M. (2019). Forecasting Bankruptcy for organizational sustainability in Pakistan. Journal of Economic and Administrative Sciences, 35(3), 183-201.

51. Jaggi, B., \& Lee, P. (2002). Earnings Management Response to Debt Covenant Violations and Debt Restructuring. Journal of Accounting, Auditing \& Finance, 17(4), 295-324.

52. Kamaluddin, A., Ishak, N., \& Mohammed, N. F. (2019). Financial Distress Prediction Through Cash Flow Ratios Analysis. Internatinal Journal of Finance Research, 10(3), 63-76.

53. Khanin, D., \& Mahto, R. V. (2012). Regulatory risk, borderline legality, fraud and financial restatement. International Journal of Accounting and Information Management, 20(4), 377-394.

54. Kim, S. Y., \& Upneja, A. (2014). Predicting restaurant financial distress using decision tree and AdaBoosted decision tree models. Economic Modelling, 36, 354-362.

55. Kirkos, E., Spathis, C., \& Manolopoulos, Y. (2007). Data Mining techniques for the detection of fraudulent financial statements, 32 (4), 995-1003.

56. Kumar, K. (2012). A comparison of bankruptcy models. International Journal of Marketing, Financial Service and Management Research, 1(4), 76-86.

57. Land, J. K. (2010). CEO turnover around earnings restatements and fraud. Pacific Accounting Review, 22(3), 180-198.

58. Lau, C. K., \& Ooi, K. W. (2016). A case study on fraudulent financial reporting: evidence from Malaysia Chee. Accounting Research Journal, 29(1), 4-19.

59. Lee, T.-S., \& Yeh, Y. H. (2004). Corporate governance and financial distress: evidence from Taiwan. Corporate Governance, 12(3), 378-388.

60. Liou, F., \& Yang, C. (2008). Predicting business failure under the existence of fraudulent financial reporting. International Journal of Accounting \& Information Management, 16(1), 74-86.

61. Mohan, A., \& Thakor, A. V. (2014). Why Do Firms Smooth Earnings ?*, 76(1), 151-192.

62. Nagar, N., \& Sen, K. (2017). Do financially distressed firms misclassify core expenses? Accounting Research Journal, 30(2), 205-223.

63. Nigrini, M. J. (2005). An assessment of the change in the incidence of earnings management around the Enron-Andersen episode. Review of Accounting and Finance, 4(1), 92-110.

64. Omar, N., Johari, Z. A., \& Smith, M. (2017). Predicting fraudulent financial reporting using artificial neural network. Journal of Financial Crime, 24(2), 362-387.

65. Perols, J. L., \& Lougee, B. A. (2011). The relation between earnings management and financial statement fraud. International Journal of Cardiology, 27(1), 39-53.

66. Pramudena, S. M. (2017). The Impact of Good Corporate Governance on Financial Distress in the Consumer Goods Sector. Journal of Finance and Banking Review, 2(4), 46-55.

67. Rosner, R. L. (2003). Earnings manipulation in failing firms. Contemporary Accounting Research, 20(2), 361-408.

68. Sekaran, U., and Bougie, R. (2013). Research Methods for Business: A Skill-Building Approach, $6^{\text {th }}$ Ed. Jhon Wiley and Sons. (pp. 240-252).

69. Song, D. B., Lee, H. Y., \& Cho, E. J. (2013). The association between earnings management and asset misappropriation. Managerial Auditing Journal, 28(6), 542-567.

70. Spathis, C., Doumpos, M., \& Zopounidis, C. (2002). Detecting falsified financial statements: a comparative study using multicriteria analysis and multivariate statistical techniques. European Accounting Review, 11(3), 509-535.

71. Spathis, C. T. (2002). Detecting false financial statements using published data: some evidence from Greece. Managerial Auditing Journal, 17(4), 179-191. 
72. Sun, J., \& Li, H. (2012). Financial distress prediction using support vector machines: Ensemble vs. individual. Applied Soft Computing, 12(8), 2254-2265.

73. Sun, J., Li, H., Huang, Q. H., \& He, K. Y. (2014). Predicting financial distress and corporate failure: A review from the state-of-the-art definitions, modeling, sampling, and featuring approaches. KnowledgeBased Systems, 57, 41-56.

74. Supriyanto, J., \& Darmawan, A. (2018). the Effect of Financial Ratio on Financial Distress in Predicting Bankruptcy. Journal of Applied Managerial Accounting, 2(1), 110-120.

75. Thai, S. B., Goh, H. H., Teh, B. H., Wong, J. C., \& Ong, T. S. (2014). A Revisited of Altman Z- Score Model for Companies Listed in Bursa Malaysia. International Journal of Business and Social Science, 5(12), 197-207.

76. Trejo-Pech, C. J. O., Weldon, R. N., \& Gunderson, M. A. (2016). Earnings Management through Specific Accruals and Discretionary Expenses: Evidence from U.S. Agribusiness Firms. Canadian Journal of Agricultural Economics, 64(1), 89-118.

77. Wang, Y., \& Campbell, M. (2010). Business Failure Prediction for Publicly Listed Companies in China. Journal of Business and Management, 16(1), 75-88.

78. Wells, P. (2002). Earnings management surrounding CEO changes. Accounting and Finance, 42(2), 169-193.

79. Yang, T. H., Hsu, J., and Yang, W. B. (2016). Firm's motives behind SEOs, earnings management, and performance. International Review of Economics and Finance, 43, 160-169.

80. Youn, H., \& Gu, Z. (2010). Predicting Korean lodging firm failures: An artificial neural network model along with a logistic regression model. International Journal of Hospitality Management, 29(1), 120127. 